\title{
The effects of heat treatment and modified atmosphere packaging on the storage stability of noni (Morinda citrifolia L.) fruit
}

\author{
${ }^{1}$ Nuraisyah, Z., ${ }^{1, *}$ Ezzat, M.A., ${ }^{1}$ Radhiah, S. and ${ }^{2}$ Prima, L. \\ ${ }^{1}$ Department of Food Technology, Faculty of Food Science and Technology, Universiti Putra Malaysia, \\ 43400, Serdang, Selangor, Malaysia \\ ${ }^{2}$ Indonesian Centre for Agricultural Postharvest Research and Development, Ministry of Agriculture, Jl. \\ Ragunan 29 Pasar Minggu Jakarta Selatan 12540, Indonesia
}

\author{
Article history: \\ Received: 22 December 2020 \\ Received in revised form: 15 \\ February 2021 \\ Accepted: 29 May 2021 \\ Available Online: 19 \\ September 2021
}

Keywords:

Hot water dipping,

Modified atmosphere

packaging,

Noni,

Postharvest treatments,

Scopoletin

\section{DOI:}

https://doi.org/10.26656/fr.2017.5(5).762

\begin{abstract}
Noni fruit (Morinda citrifolia L.) is a herbal remedy known for its therapeutic and nutritional value. However, it is perishable and subject to rapid postharvest deterioration that shortens its shelf life during storage. Therefore, this study investigated whether hot water dipping (HWD; $60^{\circ} \mathrm{C}, 1 \mathrm{~min}$ ) and Modified Atmosphere Packaging (MAP; carbon dioxide and nitrogen) could prolong noni's shelf life. The noni physicochemical properties such as colour, firmness, weight loss, total soluble solids, titratable acidity and scopoletin content were monitored during six days of storage at room temperature. During storage, the noni skin colour changed from greenish-yellow to translucent yellow, but HWD storage was stopped on day 2 due to black spots' formation. The reduction of weight loss was significantly lowest in both MAP treatments (1.39-1.74\%). Among these, $\mathrm{N}_{2}$-based had a significantly higher scopoletin content $(27.12 \mathrm{mg} / \mathrm{g})$ and firmness $(0.8 \mathrm{~N})$ compared to $\mathrm{CO}_{2}$-based, suggesting that it was the most effective postharvest treatment to efficiently prolong the shelf life and retained the quality and stability of noni during storage.
\end{abstract}

\section{Introduction}

Noni fruit (Morinda citrifolia L.) originates from tropical Asia and Australia and belongs to the Rubiaceae family. It is known as mengkudu in Malaysia, Indian mulberry, hog apple, great morinda and jo ban in other countries (Singh et al., 2020). Noni contains more than 150 types of nutraceuticals, minerals, vitamins, macro and micronutrients, and has been used effectively as a traditional medicine for the treatment of diarrhoeaintestinal parasites, diabetes, high blood pressure, kidney, menstrual cramps, skin problems and bonerelated diseases (Macpherson et al., 2007; Rethinam and Sivaraman, 2007; Yahia, 2011). The physicochemical characteristics of noni have been quantified as follows: $90 \%$ moisture, $\mathrm{pH} 3.72,9.87 \%$ dry matter, $8^{\circ} \mathrm{Bx}$ total soluble solids (TSS), $2.5 \%$ crude protein content, $0.15 \%$ crude lipid content, $11.97 \mathrm{~g} / \mathrm{L}$ of glucose, $8.27 \mathrm{~g} / \mathrm{L}$ of fructose, $3.9 \mathrm{~g} / \mathrm{L}$ of potassium, $214 \mathrm{mg} / \mathrm{L}$ of sodium, 14 $\mathrm{mg} / \mathrm{L}$ of magnesium, $28 \mathrm{mg} / \mathrm{L}$ of calcium and 155 $\mathrm{mg} / 100 \mathrm{~g}$ of vitamin $\mathrm{C}$ (Chunhieng et al., 2005). Moreover, noni contains phenolic compounds such as scopoletin, damnacathal, morindone and aucubin (Wang and $\mathrm{Su}, 2001)$. Scopoletin can regulate serotonin levels and acts as an anti-inflammatory (Moon et al., 2007) and an anti-diabetic agent to aid in insulin resistance and as an anticoagulant (Chang et al., 2015).

Noni is commonly harvested for agricultural products and marketed in liquid form to produce a beverage or medicine. Singh et al. (2007) claimed that noni's shelf life could be up to 5 to 7 days in open conditions at room temperature of $25-30^{\circ} \mathrm{C}$ with a relative humidity of $70-75 \%$. As the fruit matures, the skin changes colour from greenish-yellow to creamy yellow on day 3 , turning white after five storage days. However, rapid deterioration of noni after harvesting affects the quality (Rosalizan et al., 2010), thus influence the stability and shelf life of the fruit. According to $\mathrm{Wu}$ et al. (2019), there are 4 different stages $(0,2,4$ and 6 days) that represent the physiology phases of postharvest noni fruit. For stage I, freshly harvested noni has greenish-white, hard and smooth surface. After being harvested for 2 days (stage II), it turns whiter and softer inside, yet the surface is still hard. After 4 days (stage III), the whole fruit including the surface become very soft. Noni enters stage IV after 6 days, at which it becomes extremely soft with water-like pulp. The flesh softens quickly within a few days, accompanied by a strong rancid-like odour (Yahia, 2011). In addition, the 
physicochemical properties of the fruit undergo changes after harvesting in terms of weight, texture, titratable acidity (TA), TSS and odour, which leads to difficulties during storage for further processing or transportation.

Hence, postharvest treatments of noni may lead to better quality attributes during storage. Heat treatment using hot water dipping (HWD) is effective in retaining the firmness of the fruits such as citrus (Zhou et al., 2014) and muskmelon (Yuan et al., 2013). Furthermore, HWD for $2-3$ mins at $50-55^{\circ} \mathrm{C}$ can help prolong the stability of fruit by suppressing or killing fungal pathogen activities, and deactivate enzyme activity (Sui et al., 2016). Moreover, carbon dioxide $\left(\mathrm{CO}_{2}\right)$-based, and nitrogen $\left(\mathrm{N}_{2}\right)$-based Modified Atmosphere Packaging (MAP) may also increase the shelf life of the fruit (Koseki and Itoh, 2002). However, between HWD and MAP, none of these methods has been used on noni for postharvest treatment. We hypothesised that, even though HWD has a direct effect to inhibit the activity of fungal pathogens, it can also impact the fruit quality by enhancing ripening and senescence processes. Meanwhile, MAP will effectively preserve the fruit compared to HWD due to less exposure to the environment. Therefore, this study aims to investigate between control (untreated), $\mathrm{HWD}, \mathrm{CO}_{2}$-based and $\mathrm{N}_{2-}$ based MAP, which of these postharvest treatments could prolong noni's shelf life, retaining the quality and stability during storage.

\section{Materials and methods}

Noni was harvested from the farm at Universiti Putra Malaysia, Malaysia. The fruits had average size (10-12 $\mathrm{cm}$ length, 3-6 cm width), weighing 80-100 $\mathrm{g}$ and greenish-yellow skin. Sodium hydroxide $(\mathrm{NaOH})$, ethyl acetate $(99.8 \%)$, methanol $(99.8 \%)$ and formic acid (95\%) were chemical grade and purchased from SigmaAldrich, Germany.

\subsection{Postharvest treatments}

\subsubsection{Control}

Untreated noni (control) was placed in an open cardboard container at room temperature of $25 \pm 2^{\circ} \mathrm{C}$ and relative humidity of $70 \pm 5 \%$ up to 6 days. Four samples were taken out every day for analysis. Relative humidity was determined using a dry bulb and wet bulb temperature. The temperature difference was used to determine the percentage relative humidity according to a psychometric chart.

\subsubsection{Hot water dipping}

Hot water dipping (HWD) was performed by dipping four samples of noni for $1 \mathrm{~min}$ in a water bath at $60^{\circ} \mathrm{C}$ (Ranganna et al., 1998). After dipping, the fruits were wiped dry before storage. All samples were kept in a laboratory at room temperature of $25 \pm 2^{\circ} \mathrm{C}$ and relative humidity of $70 \pm 5 \%$ in open containers for up to 6 days. Four samples were analysed every day during storage (Grigio et al., 2015).

\subsubsection{Modified atmosphere packaging}

Each noni was packaged in $15 \times 23 \mathrm{~cm}$ high-density polyethylene (HDPE) bags and vacuum packed to ensure the package was free of atmospheric gases. The package was injected with a needle connected to the gas tank containing $\mathrm{CO}_{2}$ or $\mathrm{N}_{2}$ and sealed with tape. This is followed by storage in the open container at room temperature $\left(25 \pm 2^{\circ} \mathrm{C}\right)$ and relative humidity $(70 \pm 5 \%)$ for up to 6 days. Four packages were analysed daily, with each package containing only one fruit.

\subsection{Colour analysis}

The skin and flesh colour of each sample was determined using a chromameter (CR-400 Chroma Meter, Konica Minolta, Osaka, Japan). The flesh colour was obtained by cutting the fruit in half to obtain a sample with an average diameter of $5 \mathrm{~cm}$ to fit the chromameter. The chromaticity planes were defined by the dimensions $L^{*}, a^{*}$ and $b^{*} ; L^{*}$ indicates lightness, while $a^{*}$ and $b^{*}$ are the chromaticity coordinates in which $+a^{*}$ indicates redness, $-a^{*}$ greenness, $+b^{*}$ yellowness, and $-b^{*}$ blueness (Rosalizan et al., 2010; Azman et al., 2020). Ten replicates were measured for each fruit and the total colour difference (TCD) between four samples was calculated according to the following formula by Wrolstad and Smith (2017):

Total colour difference $(T C D)=\left[\left(L^{*}-L_{0}\right)^{2}+\left(a^{*}-a_{0}\right)^{2}+\left(b^{*}-b_{0}\right)^{2}\right]^{1 / 2}$

where, $L_{o}, a_{o}, b_{o}=$ blank values of control samples after harvest on day 0

\subsection{Determination of weight loss}

The weight of fruit was obtained initially before treatment using an electronic mass balance, then recorded every day during storage. The results were expressed as the percentage loss using the following equation:

$$
\% W_{L}=\frac{W_{i}-W_{f}}{W_{i}} \times 100
$$

Where $\% W_{L}=$ percentage weight loss, $W_{i}=$ initial fruit weight $(\mathrm{g}), W_{f}=$ final fruit weight $(\mathrm{g})$ at the indicated period (Lopez-Castaneda et al., 2010).

\subsection{Textural properties}

The firmness of the fruits was analysed using a texture analyser (TA.XT.plus, Stable Micro System, UK) with a mechanical force-displacement using a $5 \mathrm{~kg}$ 
loading cell and a $2 \mathrm{~mm}$ cylindrical flat head probe entering the noni flesh from the sagittal side. Each sample was compressed into three different sections. The force $(\mathrm{N})$ was measured with the following instrument settings: test speed of $1.50 \mathrm{~mm} / \mathrm{s}$, post-test speed of $10.00 \mathrm{~mm} / \mathrm{s}$, auto force trigger of $25.0 \mathrm{~g}$ and distance of $10 \mathrm{~mm}$ (Giongo et al., 2013).

\subsection{Determination of total soluble solids (TSS)}

Noni was homogenised for two minutes in a blender (Masuko Sangyo Co., Ltd., Kawaguchi-city, SaitamaPref., Japan) and filtered using thin cotton cloth (muslin) to obtain the juice. TSS was determined using a portable refractometer (N-1E, Brix 0-32\%, ATAGO Co., Ltd., Tokyo, Japan). The analysis was a destructive technique as the fruits were prepared in juice extract and the results were expressed as ${ }^{\circ} \mathrm{Bx}$ (Grigio et al., 2015). The number of replicates for each treatment was four.

\subsection{Determination of titratable acidity (TA)}

By using the same juice extract for the TSS analysis, TA was measured by titration with an alkaline solution (0.1 N NaOH) until pH 8.1 (Askar and Treptow, 1993). Briefly, the sample $(5 \mathrm{~mL})$ was mixed with distilled water made up to $50 \mathrm{~mL}$, filtered and titrated with $\mathrm{NaOH}$. The total TA was expressed as a percentage of citric acid and four fruits were used for each treatment:

$$
\% \text { citric acid }=\frac{V \times 64 \mathrm{~g} \times V_{m} \times 100}{V_{s} \times W \times 1000}
$$

Where $V, N, V_{m}, W$ and $V_{s}$ are mole of $0.1 \mathrm{~N}$ of $\mathrm{NaOH}$ used, normality, the quantity of volume made up, the weight of sample and volume of sample used, respectively (Thirukkumar et al., 2017).

\subsection{Determination of scopoletin content by HPLC analysis}

Approximately $100 \mathrm{~g}$ of noni was mashed and filtered through a Whatman No. 4 filter paper. Then, 10 $\mathrm{mL}$ of noni juice extract was accurately measured and extracted with a triple volume of ethyl acetate $(30 \mathrm{~mL})$. The organic phase was then combined and concentrated using a rotary evaporator at $60^{\circ} \mathrm{C}$ (Liu et al., 2005). The extracted residue was dissolved in $8 \mathrm{~mL}$ of methanol$\mathrm{H}_{2} \mathrm{O}(1: 1, \mathrm{v} / \mathrm{v})$ and filtered through a syringe nylon microfilter $(0.22 \mu \mathrm{m}$ pore size $)$ and stored at $-18^{\circ} \mathrm{C}$ for HPLC analysis.

The analysis was performed using Waters 2695 Alliance HPLC (Waters Corp., Milford, MA, USA) connected to a Waters 2414 refractive index (RI) detector, two Waters 515 HPLC pumps. A C18 column $(250 \times 4.6 \mathrm{~mm}, 5 \mu \mathrm{m})$ was used as the separation column and placed in a column oven at $40^{\circ} \mathrm{C}$. An isocratic mixture of methanol and water (30:70) containing $0.1 \%$ (v/v) formic acid was used as the mobile phase, which was filtered through a vacuum pump and degassed by sonication for $15 \mathrm{~min}$. The flow rate was adjusted to 1.0 $\mathrm{mL} / \mathrm{min}$, the auto-injection volume was $20 \mu \mathrm{L}$ and the absorbance was measured at $366 \mathrm{~nm}$ (Vipul et al., 2013). Five different concentrations $(0,20,40,60,80,100 \mathrm{mg} /$ $\mathrm{mL}$ ) of scopoletin standard (Sigma-Aldrich) solution was injected into HPLC to obtain the calibration curve. Analysis was carried out in triplicate.

\subsection{Statistical analysis}

All physicochemical and chemical analyses were conducted by one-way analysis of variance (ANOVA) using Minitab V.16 (Minitab Inc., State College, Pennsylvania, USA). Tukey's test was used to determine the significant difference $(p<0.05)$. Linear Pearson correlation was also used to evaluate correlations between colour properties, weight loss, textural properties, TSS, TA and scopoletin content.

\section{Results and discussion}

\subsection{Colour properties}

Towards the end of storage, the noni skin changed colour, from greenish-yellow to translucent yellow, with dried patches observed around the seeds in all fruit (Figure 1). The fruits became a fully translucent yellow in the control treatment, while MAP only affected the colour of the bottom of the fruit. However, fruits under HWD treatment changed drastically in appearance, with black spots on the bottom of the fruit just after 2 days of storage. Subsequently, the storage of HWD fruits was stopped on day 2 to avoid any microbial growth and unpleasant odour. Kerbel et al. (1987) reported that the peel browning could be caused by heat damage either internally or externally of fruits. Also, polyphenol oxidase (PPO) activity triggered by the heat treatment can cause necrosis (Paull and Chen, 2000), as the high temperature disrupts the non-covalent bond sustaining the enzyme structure, causing the protein to unfold and activate PPO activity (Vieille and Zeikus, 2001; Kristjánsson and Ásgeirsson, 2002).

The colour analysis is an important indicator of fruit stability. Table 1 presents the changes of $L^{*}$ (lightness), $a^{*}$ (greenness) and $b^{*}$ (yellowness) values of noni skin and flesh. Overall, HWD caused the highest changes in $L^{*}, a^{*}$ and $b^{*}$, followed by the control and MAP treatments. The lightness, greenness, and yellowness of noni skin after HWD changed significantly $(p<0.05)$ on days 1 and 3 for the control treatment. In all treatments, $L^{*}$ decreased from $71.0-74.5$ on day 0 to $49.4-54.6$ on day 6 , indicating that the noni skin became darker. Most treatments resulted in an increment of $a^{*}$ from negative towards positive and reduced $b^{*}$ over time. However, 
Figure 1. Images of postharvest treated Noni during storage. HWD: Hot water dipping; MAP: Modified atmosphere packaging; $\mathrm{CO}_{2}$ : Carbon dioxide gas; $\mathrm{N}_{2}$ : Nitrogen gas

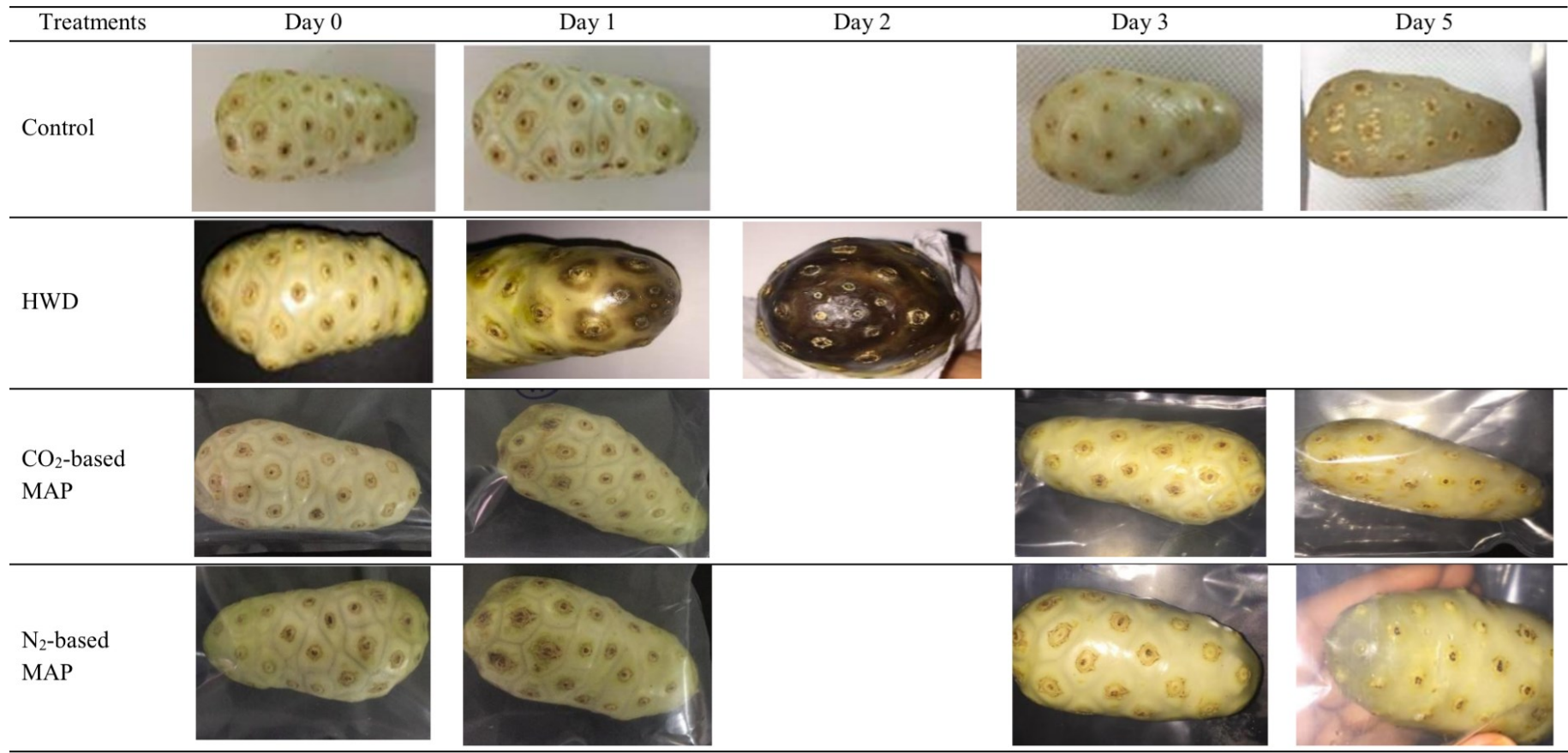

there was a fluctuation in $a^{*}$, increasing trend in $\mathrm{N}_{2-}$ based MAP, which may be due to the different stages of noni's maturity on the specific tree (Nelson, 2003). Moreover, noni skin becomes translucent yellow as the fruit matures; thus, the skin becomes less yellow and darker in colour. There was a positive correlation between $L^{*}$ and $b^{*}$ values $(\mathrm{R}=0.747, \mathrm{p}<0.05)$, supporting the findings that a decrease in $L^{*}$ also resulted in the decline of $b^{*}$.

The fruits subjected to HWD had the highest TCD (19.3 \pm 7.6$)$ after day 2 compared to the control and MAP treatments. The TCD for MAP treatment started to rapidly increase $(\mathrm{p}<0.05)$ after day 4 , with a significantly negative $(\mathrm{p}<0.05)$ coefficient between TCD and $L^{*}(\mathrm{R}=$ $-0.806)$ and $b^{*}(\mathrm{R}=-0.821)$, proving that the reduction in $L^{*}$ and $b^{*}$ increased the TCD of Noni skins during storage. According to Singh et al. (2007), Noni changes colour from green to greenish-white, whitish, creamy, translucent, then brown and becomes softer in texture. As the fruit ripens, the colour turns white, which becomes darker, signalling senescence. Janick and Paull (2008) described that Noni would change to light green colour when unripe and whitish-yellow when ripe during the hard-white stage, becoming soft and translucent yellow after several days. The colour changes occur due to chlorophyll's breakdown during ripening, causing the fruit to change colour from green to yellow. Furthermore, Koseki and Itoh (2002) reported that packaging helps slow down the browning effect of freshcut vegetables. Browning can occur if the fruit is sliced, crushed, or aged due to PPO enzyme breakdown and oxygen contact in the air.

Regarding the noni flesh, the control treatment showed the highest TCD after 6 days in storage, followed by $\mathrm{N}_{2}$-based and $\mathrm{CO}_{2}$-based MAP. Notably, noni flesh from the HWD treatment had a lower TCD than the skin, suggesting that heat treatment affects the skin more than flesh. Moreover, $L^{*}$ and $b^{*}$ started to reduce significantly $(\mathrm{p}<0.05)$ after days 3 and 4 , respectively for both control and MAP treatments. Amongst all treatments, the control sample had the significantly $(\mathrm{p}<0.05)$ highest decrease in $L^{*}$ of flesh, from $\sim 67.7$ on day 0 to $\sim 39.3$ on day 6 , indicating a reduction in lightness, followed by $\mathrm{CO}_{2}$-based and $\mathrm{N}_{2}$ based MAP with final $L^{*}$ values of $\sim 44.3$ and $\sim 43.5$, respectively. The decrease in $L^{*}$ significantly increased the TCD of noni flesh as indicated by the negative correlation $(\mathrm{R}=-0.954, \mathrm{p}<0.05)$. The smaller changes in TCD suggest that MAP packaging efficiently preserved noni flesh's colour during storage compared to other treatments.

\subsection{Weight loss}

Figure 2 shows the weight loss which occurred during storage. The control, $\mathrm{CO}_{2}$-based and $\mathrm{N}_{2}$-based MAP were stored for 6 days and only 2 days for HWD treatment. Storage for HWD stopped on day 2 due to black spot formation and day 6 for other treatments due to the condition of the fruits that became translucent yellow with very fragile flesh. Fruits subjected to HWD had a rapid weight loss as early as day one of storage because heat treatment promoted the rearrangement of epicuticular layers that led to weight loss. Also, weight loss is caused by the loss of respiratory gases and water vapour from the fruits (Amin and Hossain, 2012.). The control treatment had the highest weight loss which started on day 2, while the $\mathrm{CO}_{2}$-based and $\mathrm{N}_{2}$-based 
Table 1. Changes in $L^{*}, a^{*}, b^{*}$ values and total colour difference (TCD) of Noni during different storage treatments.

\begin{tabular}{|c|c|c|c|c|c|c|c|}
\hline \multirow{2}{*}{ Treatments } & \multicolumn{7}{|c|}{ Storage time (days) } \\
\hline & 0 & 1 & 2 & 3 & 4 & 5 & 6 \\
\hline \multicolumn{8}{|l|}{ Skin } \\
\hline \multicolumn{8}{|l|}{$L^{*}$ value } \\
\hline Control & $71.0 \pm 1.1^{\mathrm{Ba}}$ & $73.8 \pm 1.7^{\mathrm{Aa}}$ & $74.5 \pm 0.7^{\mathrm{Aa}}$ & $65.6 \pm 2.0^{\mathrm{Ab}}$ & $59.0 \pm 1.7^{\mathrm{Ac}}$ & $54.8 \pm 1.9^{\mathrm{Ad}}$ & $54.6 \pm 1.0^{\mathrm{Ad}}$ \\
\hline HWD & $74.5 \pm 1.2^{\mathrm{Aa}}$ & $60.0 \pm 0.8^{\mathrm{Bb}}$ & $57.0 \pm 6.5^{\mathrm{Cb}}$ & - & - & - & - \\
\hline $\mathrm{CO}_{2}$-based MAP & $71.0 \pm 1.1^{\mathrm{Ba}}$ & $70.6 \pm 2.5^{\mathrm{Aa}}$ & $65.9 \pm 3.2^{\mathrm{Bb}}$ & $62.9 \pm 2.0^{\mathrm{Aab}}$ & $55.0 \pm 8.2^{\mathrm{Abc}}$ & $50.8 \pm 2.1^{\mathrm{Ac}}$ & $49.4 \pm 3.6^{\mathrm{Bc}}$ \\
\hline $\mathrm{N}_{2}$-based MAP & $71.0 \pm 1.1^{\mathrm{Ba}}$ & $70.0 \pm 1.9^{\mathrm{Aa}}$ & $68.3 \pm 1.4^{\mathrm{ABa}}$ & $66.3 \pm 3.1^{\text {Aab }}$ & $57.6 \pm 7.2^{\mathrm{Abc}}$ & $56.9 \pm 6.8^{\mathrm{Abc}}$ & $50.4 \pm 2.4^{\mathrm{ABc}}$ \\
\hline \multicolumn{8}{|l|}{$a^{*}$ value } \\
\hline Control & $-0.6 \pm 1.1^{\mathrm{Ac}}$ & $-0.2 \pm 0.7^{\mathrm{ABbc}}$ & $-0.6 \pm 1.2^{\mathrm{ABc}}$ & $0.7 \pm 0.3^{\text {Aabc }}$ & $1.2 \pm 0.8^{\mathrm{Aab}}$ & $2.0 \pm 0.5^{\mathrm{Aa}}$ & $2.3 \pm 0.2^{\mathrm{Aa}}$ \\
\hline HWD & $-1.1 \pm 0.7^{\mathrm{Ab}}$ & $1.7 \pm 1.4^{\mathrm{Aa}}$ & $1.7 \pm 1.3^{\mathrm{Aa}}$ & - & - & - & - \\
\hline $\mathrm{CO}_{2}$-based MAP & $-0.6 \pm 1.1^{\mathrm{Aa}}$ & $-1.5 \pm 1.7^{\mathrm{BCa}}$ & $-1.6 \pm 1.1^{\mathrm{Ba}}$ & $-0.5 \pm 1.0^{\mathrm{Aa}}$ & $0.5 \pm 1.9^{\mathrm{Aa}}$ & $0.6 \pm 2.7^{\mathrm{Aa}}$ & $0.4 \pm 1.9^{\mathrm{Aa}}$ \\
\hline $\mathrm{N}_{2}$-based MAP & $-0.6 \pm 1.1^{\mathrm{Aa}}$ & $-3.4 \pm 1.7^{\mathrm{Ca}}$ & $-3.2 \pm 1.1^{\mathrm{Ba}}$ & $-0.1 \pm 0.6^{\mathrm{Aa}}$ & $3.8 \pm 7.6^{\mathrm{Aa}}$ & $-0.1 \pm 2.6^{\mathrm{Aa}}$ & $1.6 \pm 0.4^{\mathrm{Aa}}$ \\
\hline \multicolumn{8}{|l|}{ b*value } \\
\hline Control & $30.9 \pm 3.1^{\mathrm{Aa}}$ & $24.6 \pm 1.1^{\mathrm{Ab}}$ & $32.5 \pm 3.0^{\mathrm{Aa}}$ & $23.9 \pm 2.7^{\mathrm{Ab}}$ & $23.6 \pm 0.6^{\mathrm{Ab}}$ & $17.5 \pm 1.1^{\mathrm{Ac}}$ & $15.8 \pm 1.0^{\mathrm{Bc}}$ \\
\hline HWD & $31.9 \pm 1.4^{\mathrm{Aa}}$ & $27.8 \pm 1.7^{\text {Aab }}$ & $24.9 \pm 4.1^{\mathrm{Bb}}$ & - & - & - & - \\
\hline $\mathrm{CO}_{2}$-based MAP & $30.9 \pm 3.1^{\mathrm{Aa}}$ & $25.6 \pm 2.2^{\mathrm{Aab}}$ & $25.8 \pm 2.8^{\mathrm{Bab}}$ & $22.8 \pm 0.5^{\mathrm{Abc}}$ & $17.4 \pm 3.8^{\mathrm{Bc}}$ & $19.7 \pm 4.8^{\mathrm{Abc}}$ & $20.6 \pm 4.1^{\mathrm{Abc}}$ \\
\hline $\mathrm{N}_{2}$-based MAP & $30.9 \pm 3.1^{\mathrm{Aa}}$ & $29.0 \pm 3.5^{\mathrm{Aa}}$ & $26.6 \pm 2.3^{\mathrm{ABab}}$ & $21.3 \pm 1.0^{\mathrm{Abc}}$ & $19.0 \pm 3.5^{\mathrm{ABc}}$ & $19.7 \pm 4.4^{\mathrm{Ac}}$ & $16.3 \pm 0.5^{\mathrm{ABc}}$ \\
\hline \multicolumn{8}{|l|}{ TCD } \\
\hline Control & - & $7.1 \pm 2.6^{\mathrm{Bc}}$ & $4.4 \pm 0.2^{\mathrm{Bc}}$ & $10.1 \pm 2.3^{\mathrm{Abc}}$ & $14.4 \pm 3.0^{\mathrm{Ab}}$ & $21.3 \pm 3.3^{\mathrm{Aa}}$ & $22.6 \pm 3.0^{\mathrm{Aa}}$ \\
\hline HWD & - & $15.5 \pm 2.2^{\mathrm{Aa}}$ & $19.3 \pm 7.6^{\mathrm{Aa}}$ & - & - & - & - \\
\hline $\mathrm{CO}_{2}$-based MAP & - & $6.3 \pm 2.3^{\mathrm{Bb}}$ & $8.4 \pm 4.3^{\mathrm{Bb}}$ & $11.7 \pm 2.3^{\mathrm{Ab}}$ & $21.5 \pm 7.1^{\mathrm{Aa}}$ & $23.5 \pm 3.3^{\mathrm{Aa}}$ & $24.6 \pm 2.8^{\mathrm{Aa}}$ \\
\hline $\mathrm{N}_{2}$-based MAP & - & $4.8 \pm 1.6^{\mathrm{Bc}}$ & $7.0 \pm 2.6^{\mathrm{Bc}}$ & $11.3 \pm 2.8^{\mathrm{Abc}}$ & $20.7 \pm 6.3^{\mathrm{Aab}}$ & $18.9 \pm 7.0^{\mathrm{Aab}}$ & $25.4 \pm 4.0^{\mathrm{Aa}}$ \\
\hline \multicolumn{8}{|l|}{ Flesh } \\
\hline \multicolumn{8}{|l|}{ L*value } \\
\hline Control & $67.7 \pm 1.0^{\mathrm{Aa}}$ & $64.6 \pm 1.3^{\mathrm{Aab}}$ & $60.3 \pm 3.5^{\mathrm{Bbc}}$ & $59.9 \pm 0.8^{\mathrm{Ac}}$ & $55.3 \pm 1.8^{\mathrm{Ad}}$ & $40.3 \pm 2.0^{\mathrm{Ae}}$ & $39.3 \pm 1.1^{\mathrm{Be}}$ \\
\hline HWD & $65.6 \pm 4.5^{\mathrm{Aa}}$ & $66.2 \pm 3.1^{\mathrm{Aa}}$ & $69.1 \pm 2.8^{\mathrm{Aa}}$ & - & - & - & - \\
\hline $\mathrm{CO}_{2}$-based MAP & $67.7 \pm 1.0^{\mathrm{Aa}}$ & $57.1 \pm 0.9^{\mathrm{Bb}}$ & $56.8 \pm 1.7^{\mathrm{BCb}}$ & $54.2 \pm 2.0^{\mathrm{Bb}}$ & $45.9 \pm 5.4^{\mathrm{Bc}}$ & $44.2 \pm 4.8^{\mathrm{Ac}}$ & $44.3 \pm 0.9^{\mathrm{Ac}}$ \\
\hline $\mathrm{N}_{2}$-based MAP & $67.7 \pm 1.0^{\mathrm{Aa}}$ & $57.2 \pm 1.2^{\mathrm{Bb}}$ & $54.5 \pm 1.8^{\mathrm{Cb}}$ & $54.2 \pm 2.1^{\mathrm{Bb}}$ & $47.3 \pm 3.4^{\mathrm{Bc}}$ & $46.8 \pm 4.4^{\mathrm{Ac}}$ & $43.5 \pm 1.1^{\mathrm{Ac}}$ \\
\hline \multicolumn{8}{|l|}{$a *$ value } \\
\hline Control & $2.1 \pm 0.6^{\mathrm{Aa}}$ & $2.6 \pm 0.5^{\mathrm{ABa}}$ & $2.4 \pm 0.4^{\mathrm{Ba}}$ & $0.7 \pm 0.2^{\mathrm{Bb}}$ & $1.2 \pm 0.2^{\mathrm{Bb}}$ & $2.2 \pm 0.3^{\mathrm{Aa}}$ & $2.4 \pm 0.1^{\mathrm{Ba}}$ \\
\hline HWD & $2.5 \pm 0.1^{\mathrm{Ab}}$ & $3.5 \pm 0.4^{\mathrm{Aa}}$ & $3.2 \pm 0.3^{\mathrm{Aa}}$ & - & - & - & - \\
\hline $\mathrm{CO}_{2}$-based MAP & $2.1 \pm 0.6^{\mathrm{Abc}}$ & $2.3 \pm 0.5^{\mathrm{Babc}}$ & $2.6 \pm 0.4^{\mathrm{ABabc}}$ & $1.7 \pm 0.1^{\mathrm{Ac}}$ & $2.4 \pm 0.4^{\mathrm{Aabc}}$ & $2.7 \pm 0.4^{\mathrm{Aab}}$ & $3.0 \pm 0.3^{\mathrm{Aa}}$ \\
\hline $\mathrm{N}_{2}$-based MAP & $2.1 \pm 0.6^{\mathrm{Aa}}$ & $2.2 \pm 0.4^{\mathrm{Ba}}$ & $1.9 \pm 0.3^{\mathrm{Ba}}$ & $2.1 \pm 0.3^{\mathrm{Aa}}$ & $2.0 \pm 0.7^{\mathrm{ABa}}$ & $2.1 \pm 0.5^{\mathrm{Aa}}$ & $2.7 \pm 0.4^{\mathrm{ABa}}$ \\
\hline \multicolumn{8}{|l|}{$b^{*}$ value } \\
\hline Control & $12.6 \pm 0.4^{\mathrm{Bb}}$ & $17.9 \pm 0.5^{\mathrm{Aa}}$ & $16.6 \pm 0.7^{\mathrm{Aa}}$ & $13.0 \pm 0.3^{\mathrm{Ab}}$ & $12.2 \pm 0.5^{\mathrm{Ab}}$ & $6.6 \pm 0.5^{\mathrm{Ac}}$ & $7.1 \pm 0.3^{\mathrm{Ac}}$ \\
\hline HWD & $20.3 \pm 1.0^{\mathrm{Aa}}$ & $13.6 \pm 0.5^{\mathrm{Bb}}$ & $12.6 \pm 0.8^{\mathrm{Bb}}$ & - & - & - & - \\
\hline $\mathrm{CO}_{2}$-based MAP & $12.6 \pm 4.0^{\mathrm{Bab}}$ & $13.1 \pm 0.8^{\mathrm{Ba}}$ & $12.5 \pm 1.0^{\mathrm{Bab}}$ & $10.8 \pm 0.7^{\text {Babc }}$ & $7.4 \pm 1.3^{\mathrm{Bc}}$ & $8.6 \pm 1.6^{\mathrm{Abc}}$ & $6.9 \pm 0.4^{\mathrm{ABc}}$ \\
\hline $\mathrm{N}_{2}$-based MAP & $12.6 \pm 4.0^{\mathrm{Ba}}$ & $12.8 \pm 1.2^{\mathrm{Ba}}$ & $11.7 \pm 1.0^{\mathrm{Bab}}$ & $9.6 \pm 0.9^{\mathrm{Babc}}$ & $7.9 \pm 1.6^{\mathrm{Bbc}}$ & $7.8 \pm 1.1^{\mathrm{Abc}}$ & $6.3 \pm 0.3^{\mathrm{Bc}}$ \\
\hline \multicolumn{8}{|l|}{ TCD } \\
\hline Control & - & $6.7 \pm 3.2^{\mathrm{Bc}}$ & $8.8 \pm 4.5^{\mathrm{Abc}}$ & $8.8 \pm 0.3^{\mathrm{Bbc}}$ & $13.1 \pm 1.8^{\mathrm{Bb}}$ & $28.3 \pm 3.0^{\mathrm{Aa}}$ & $29.1 \pm 2.5^{\mathrm{Aa}}$ \\
\hline HWD & - & $8.0 \pm 1.5^{\mathrm{ABa}}$ & $9.1 \pm 2.2^{\mathrm{Aa}}$ & - & - & - & - \\
\hline $\mathrm{CO}_{2}$-based MAP & - & $11.1 \pm 1.2^{\mathrm{Ab}}$ & $11.7 \pm 1.7^{\mathrm{Ab}}$ & $14.3 \pm 2.0^{\mathrm{Ab}}$ & $22.8 \pm 4.5^{\mathrm{Aa}}$ & $24.2 \pm 3.4^{\mathrm{Aa}}$ & $24.3 \pm 2.3^{\mathrm{Ba}}$ \\
\hline $\mathrm{N}_{2}$-based MAP & - & $11.0 \pm 1.8^{\mathrm{ABb}}$ & $13.7 \pm 1.6^{\mathrm{Ab}}$ & $14.5 \pm 3.2^{\mathrm{Ab}}$ & $21.4 \pm 3.1^{\mathrm{Aa}}$ & $21.6 \pm 5.3^{\mathrm{Aa}}$ & $25.2 \pm 1.9^{\mathrm{ABa}}$ \\
\hline
\end{tabular}

${ }^{a} \mathrm{HWD}$ : Hot water dipping; MAP: Modified atmosphere packaging; $\mathrm{CO}_{2}$ : Carbon dioxide gas; $\mathrm{N}_{2}$ : Nitrogen gas. Figures in parentheses indicate the standard deviation. Values with the same lowercase superscript in each column or uppercase superscript in each row are not significantly different ( $\mathrm{p}>0.05)$.

MAP showed the lowest weight loss beginning on day 4. Serdar and Usanmaz (2017) reported that MAP protects the fruit, reducing pomegranates' weight loss. Furthermore, MAP provides differences in the gas concentration within the packaging due to the fruit's dynamic interaction with the fruit's metabolic and biochemical processes. When the fruit respires, oxygen is consumed and $\mathrm{CO}_{2}$, ethylene and water vapour are produced and regulated in the MAP system, thus preserve the fruit.

The reduction in weight of noni was related to the water loss. Migration of water occurs due to 
transpiration, which then evaporates from the fruit's surface to the surroundings (Kader, 2002). These results are in agreement with Singh et al. (2007) and similar to those obtained for date palm by Hazbavi et al. (2015) as well as Park and Jung (1996) and Perez et al. (2004) who reported a rapid weight loss in citrus and avocado fruits, respectively upon exposure to heat treatments. However, Grigio et al. (2015) observed that camu-camu fruits without packaging had a higher weight loss $(15 \%)$ than packaged fruits $(8-9 \%)$, concluding that the packaging method help to retain the water in the fruit.

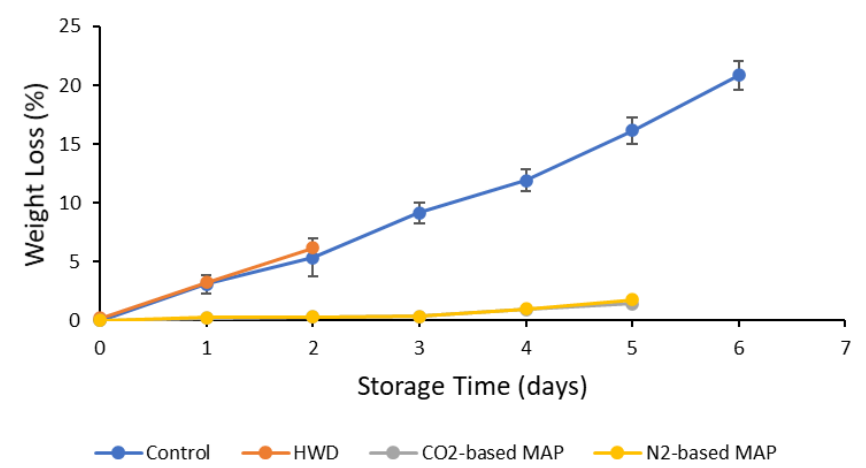

Figure 2. Weight loss (\%) of Noni in different storage treatments. HWD: Hot water dipping; MAP: Modified atmosphere packaging; $\mathrm{CO}_{2}$ : Carbon dioxide gas; $\mathrm{N}_{2}$ : Nitrogen gas

\subsection{Textural properties}

Firmness is an indicator of immaturity or overmaturity of fruits and Table 2 presents the changes in firmness for each treatment during storage. HWD treated noni were removed on day 2 due to the spoilage and formation of black spots and had an $8.0 \mathrm{~N}$ reduction in the initial firmness, followed by control, $\mathrm{N}_{2}$-based and $\mathrm{CO}_{2}$-based MAP. Due to the spoilage condition of fruits from each treatment from Figure 1, storage was stopped on certain days even though the texture properties were acceptable. The appearance of fruits was considered an important factor that influences consumers' preferences. Grigio et al. (2015) mentioned that better-looking camucamu fruits were stored for further analysis and fruits with loss of brightness and colouration were removed from the experiment even though the texture properties were acceptable.

The firmness of the control treatment started to rapidly $(p<0.05)$ decrease after day 3 , whereas MAP treatments caused a gradual reduction, with $\mathrm{N}_{2}$-based MAP was found to have the highest firmness after 6 days in storage compared to $\mathrm{CO}_{2}$-based MAP and control treatments. There was a negative correlation between firmness and TA $(\mathrm{R}=-0.736, \mathrm{p}<0.05)$, suggesting that the decreased firmness produced significantly higher TA in noni. Also, strong negative correlations were detected between TCD of skin $(\mathrm{R}=-0.819, \mathrm{p}<0.05)$ and flesh $(\mathrm{R}$
$=-0.804, \mathrm{p}<0.05)$, revealing that the decreased firmness also significantly changed the TCD of noni during storage. Arendse et al. (2014) also reported that pomegranate's firmness decreased significantly in all storage treatments at chilled and room temperature. Firmness is related to the softening promoting enzyme (polygalacturonase), which is responsible for the breakdown of pectin, resulting in a short storage period of HWD samples compared to the other treatments in this study.

\subsection{Total soluble solid and titratable acidity}

According to Table 2, noni subjected to HWD had higher total soluble solids (TSS) compared to other treatments on day 2. Thirukkumar et al. (2017) also stated that the TSS of noni significantly $(\mathrm{p}<0.05)$ increased up to $13.0^{\circ} \mathrm{Bx}$ as the blanching time increased. After 6 days, the TSS of the control treatment was maintained at $\sim 9.6^{\circ} \mathrm{Bx}$, while the readings in $\mathrm{CO}_{2}$-based and $\mathrm{N}_{2}$-based MAP treatments started to decrease after day 3 to 8.6 and $8.3^{\circ} \mathrm{Bx}$, respectively. Grigio et al. (2015) findings regarding camu-camu fruit were in contrast with the control and HWD samples but in line with MAP treatments. They claimed that all treatments reduced the soluble solid content during storage days, due to compounds such as carbohydrates, organic acids, proteins, fat and mineral being used as an energy source for metabolic changes in plant tissues as the fruits progressed to senescence.

Also, TSS was affected by the concentration of sugar in the fruit. According to Grigio et al. (2015), the increase of soluble solids in unpackaged fruits was related to weight loss that increased the sugar concentration in the pulp. Hazbavi et al. (2015) reported that increasing soluble solids was due to water escape throughout storage and the enzymatic breakdown of larger polysaccharides to smaller sugar compounds. Gluconeogenesis is a metabolic process producing new glucose from non-carbohydrate carbon sources, which can occur in Noni stored in an open container. In contrast, the MAP treatments with a specific atmosphere decreased the TSS values due to metabolic changes. The packaging also caused water condensation that produced water vapour, which increased the amount of moisture, thus reducing the TSS. Linke and Geyer (2013) previously reported that fruit packaging promotes water condensation, leading to high humidity and reduced water loss. Furthermore, Hossain et al. (2014) observed that the TSS increased during the storage of mango due to the degradation of cell walls and hydrolysis of starch. TSS is directly proportional to the degree of fruit ripening, which positively relates to the percentage weight loss and storage period. 
Table 2. Changes in the firmness, total soluble solids (TSS) and titratable acidity (TA) of Noni during different storage treatments.

\begin{tabular}{|c|c|c|c|c|c|c|c|}
\hline \multirow{2}{*}{ Treatments } & \multicolumn{7}{|c|}{ Storage time (days) } \\
\hline & 0 & 1 & 2 & 3 & 4 & 5 & 6 \\
\hline \multicolumn{8}{|l|}{$\overline{\text { Firmness (N) }}$} \\
\hline Control & $21.3 \pm 4.6^{\mathrm{Aa}}$ & $16.3 \pm 4.3^{\mathrm{Aab}}$ & $13.4 \pm 2.8^{\mathrm{Bb}}$ & $1.2 \pm 0.3^{\mathrm{Bc}}$ & $0.6 \pm 0.1^{\mathrm{Bc}}$ & $0.6 \pm 0.1^{\mathrm{Bc}}$ & $0.5 \pm 0.1^{\mathrm{Bc}}$ \\
\hline HWD & $26.0 \pm 0.7^{\mathrm{Aa}}$ & $18.2 \pm 2.0^{\mathrm{Ab}}$ & $18.0 \pm 1.9^{\mathrm{Ab}}$ & - & - & - & - \\
\hline $\mathrm{CO}_{2}$-based MAP & $22.0 \pm 2.6^{\mathrm{Aa}}$ & $20.8 \pm 3.0^{\mathrm{Aa}}$ & $19.3 \pm 1.8^{\mathrm{Aa}}$ & $9.7 \pm 0.4^{\mathrm{Ab}}$ & $1.4 \pm 0.4^{\mathrm{ABc}}$ & $0.8 \pm 0.1^{\mathrm{Bc}}$ & $0.5 \pm 0.1^{\mathrm{Bc}}$ \\
\hline $\mathrm{N}_{2}$-based MAP & $21.3 \pm 3.0^{\mathrm{Aa}}$ & $19.0 \pm 4.7^{\mathrm{Aa}}$ & $14.8 \pm 0.3^{\mathrm{ABab}}$ & $9.3 \pm 0.5^{\mathrm{Abc}}$ & $4.3 \pm 2.0^{\mathrm{Acd}}$ & $1.9 \pm 0.1^{\mathrm{Ad}}$ & $0.8 \pm 0.1^{\mathrm{Ad}}$ \\
\hline \multicolumn{8}{|l|}{$\overline{\text { TSS ( }}{ }^{\circ}$ Brix) } \\
\hline Control & $9.7 \pm 0.6^{\mathrm{Abc}}$ & $10.3 \pm 0.5^{\mathrm{Aab}}$ & $9.6 \pm 0.5^{\mathrm{ABbcd}}$ & $8.4 \pm 0.5^{\mathrm{Bcd}}$ & $9.4 \pm 1.1^{\mathrm{Abcd}}$ & $8.3 \pm 0.2^{\mathrm{Ad}}$ & $9.6 \pm 0.5^{\mathrm{Abcd}}$ \\
\hline HWD & $9.5 \pm 0.5^{\mathrm{Ab}}$ & $11.0 \pm 0.8^{\mathrm{Aa}}$ & $10.5 \pm 0.7^{\mathrm{Aab}}$ & - & - & - & - \\
\hline $\mathrm{CO}_{2}$-based MAP & $9.5 \pm 0.6^{\mathrm{Aab}}$ & $10.3 \pm 1.0^{\mathrm{Aa}}$ & $8.3 \pm 0.4^{\mathrm{BCc}}$ & $9.5 \pm 0.5^{\mathrm{Ab}}$ & $9.1 \pm 0.6^{\mathrm{Abc}}$ & $8.8 \pm 0.2^{\mathrm{Abc}}$ & $8.6 \pm 0.4^{\mathrm{Bbc}}$ \\
\hline $\mathrm{N}_{2}$-based MAP & $9.8 \pm 0.4^{\mathrm{Aa}}$ & $8.6 \pm 0.5^{\mathrm{Bab}}$ & $7.2 \pm 1.5^{\mathrm{Cb}}$ & $9.2 \pm 0.5^{\mathrm{ABa}}$ & $9.1 \pm 0.7^{\mathrm{Aa}}$ & $8.9 \pm 0.6^{\mathrm{Aab}}$ & $8.3 \pm 0.3^{\mathrm{Bab}}$ \\
\hline \multicolumn{8}{|l|}{ TA (\%) } \\
\hline Control & $0.4 \pm 0.1^{\mathrm{Ac}}$ & $0.4 \pm 0.1^{\mathrm{ABc}}$ & $0.5 \pm 0.7^{\mathrm{Ac}}$ & $0.5 \pm 0.1^{\mathrm{Ac}}$ & $0.7 \pm 0.3^{\mathrm{Ab}}$ & $0.8 \pm 0.1^{\mathrm{Aab}}$ & $0.9 \pm 0.3^{\mathrm{Aab}}$ \\
\hline HWD & $0.3 \pm 0.1^{\mathrm{Ab}}$ & $0.5 \pm 0.1^{\mathrm{Aa}}$ & $0.4 \pm 0.1^{\mathrm{Aa}}$ & - & - & - & - \\
\hline $\mathrm{CO}_{2}$-based MAP & $0.3 \pm 0.1^{\text {Acd }}$ & $0.2 \pm 0.1^{\mathrm{Bd}}$ & $0.4 \pm 0.1^{\mathrm{Abc}}$ & $0.3 \pm 0.1^{\mathrm{Bcd}}$ & $0.5 \pm 0.1^{\mathrm{Bab}}$ & $0.5 \pm 0.1^{\mathrm{Bab}}$ & $0.7 \pm 0.1^{\mathrm{Ba}}$ \\
\hline $\mathrm{N}_{2}$-based MAP & $0.4 \pm 0.1^{\text {Acd }}$ & $0.3 \pm 0.2^{\mathrm{Bd}}$ & $0.4 \pm 0.1^{\mathrm{Abcd}}$ & $0.5 \pm 0.1^{\text {Aabc }}$ & $0.5 \pm 0.1^{\mathrm{Bab}}$ & $0.6 \pm 0.1^{\mathrm{Ba}}$ & $0.6 \pm 0.1^{\mathrm{Ba}}$ \\
\hline
\end{tabular}

${ }^{a} \mathrm{HWD}$ : Hot water dipping; MAP: Modified atmosphere packaging; $\mathrm{CO}_{2}$ : Carbon dioxide gas; $\mathrm{N}_{2}$ : Nitrogen gas. Figures in parentheses indicate the standard deviation. Values with the same lowercase superscript in each column or uppercase superscript in each row are not significantly different ( $p>0.05)$.

Furthermore, titratable acidity (TA) reflects the amount of acid as the fruit ripening and acid is responsible for the sweetness by transforming into sugar. As shown in Table 2, TA significantly increased $(\mathrm{p}<0.05)$ after day 1 for HWD and day 4 for control and MAP treatments. During day 6 , the TA was highest in the control, followed by $\mathrm{CO}_{2}$-based and $\mathrm{N}_{2}$-based MAP treatments. HWD had a lower TA value on day 0 than other treatments, in line with a study by Shen et al. (2013) whereas fruit treated with high temperature had a lower TA due to leaching of the tenoplast membrane after heat treatment. However, Arendse et al. (2014) reported that lack of consistency in TA value could be because the moisture loss contributed to the high organic acids with increased temperature. Moreover, there was a positive correlation $(\mathrm{R}=0.714, \mathrm{p}<0.05)$ between $\mathrm{TA}$ and weight loss, demonstrating that the increase in weight loss also resulted in the higher $\mathrm{TA}$ in noni during storage.

Grigio et al. (2015) reported that TA for all treatments had a small increase at the beginning of storage due to moisture loss causing organic acids to be more concentrated, which later decreased due to the natural process of maturation and fruit senescence because organic acids acted as an energy source. Hossain et al. (2014) suggested that the significant decrease in the TA of mango during storage is due to their utilisation as substrates for respiration. In contrast, this study showed an increment in TA for each treatment over time, similar to a report by Rosalizan et al. (2010) of Sambucus nigra L., which suggested that the changes in TA during storage were due to the predominant free amino acids in fully developed fruits. Amino acids have been detected in noni's early and senescence stages, with leucine being the highest as the fruit matured (Golden and Lindsay, 2012), indicating an increase in TA. Also, the higher TA also significantly $(p<0.05)$ increased the TCD of noni skin and flesh, as supported by the positive correlations, $\mathrm{R}=0.630$ and $\mathrm{R}=0.693$, respectively.

\subsection{Scopoletin content}

Scopoletin is known for its anti-fungal, antiinflammatory, anti-allergy, and anti-angiogenesis effects (Li et al., 2015). The scopoletin content of noni depends on the maturity of the fruit and postharvest treatment. As mentioned by Moon et al. (2007), scopoletin helps to control the serotonin level in the body. According to a study by Deng et al. (2007), scopoletin content in noni juice extract as measured by HPLC ranged between 0.88 $\mathrm{mg} / \mathrm{g}$ and $34.01 \mathrm{mg} / \mathrm{g}$, suggesting that the results in this study $(6.32-28.55 \mathrm{mg} / \mathrm{g})$ were acceptable. Overall, the scopoletin content was higher on day 0 , followed by a decrease, then increased towards the end of storage as quantified by HPLC (Table 3 and Figure 3). Notably, a significantly $(\mathrm{p}<0.05)$ lower scopoletin content was found in noni subjected to HWD on day 0 compared to other treatments, followed by a significant $(p<0.05)$ decrease, then increase during day 1 and 2, respectively, yet the concentration was lower than day 0 . In contrast, Basar et al. (2010) observed that HWD had a higher value on day 2 compared to day 0 due to heat concentration which increased the relative concentration of scopoletin. The control treatment had the highest 
Table 3. Scopoletin concentrations ( $\mathrm{mg} / \mathrm{g})$ in Noni as quantified by HPLC during different storage treatments.

\begin{tabular}{lccccc}
\hline \multirow{2}{*}{ Treatments } & \multicolumn{5}{c}{ Scopoletin concentration $(\mathrm{mg} / \mathrm{g})$} \\
\cline { 2 - 6 } & \multicolumn{5}{c}{ Storage time (days) } \\
\cline { 2 - 6 } & 0 & 1 & 2 & 3 & 5 \\
\hline Control & $28.55 \pm 0.03^{\mathrm{Aa}}$ & $15.10 \pm 0.03^{\mathrm{Ad}}$ & - & $18.64 \pm 0.03^{\mathrm{Ac}}$ & $18.53 \pm 0.02^{\mathrm{Cc}}$ \\
$\mathrm{HWD}$ & $11.08 \pm 0.04^{\mathrm{Ba}}$ & $6.32 \pm 0.11^{\mathrm{Dc}}$ & $9.50 \pm 0.02^{\mathrm{b}}$ & - & - \\
$\mathrm{CO}_{2}$-based MAP & $27.55 \pm 0.05^{\mathrm{Aa}}$ & $14.82 \pm 0.05^{\mathrm{Ad}}$ & - & $15.27 \pm 0.01^{\mathrm{Cc}}$ & $22.02 \pm 0.08^{\mathrm{Bb}}$ \\
$\mathrm{N}_{2}$-based MAP & $28.00 \pm 0.03^{\mathrm{Aa}}$ & $13.97 \pm 0.01^{\mathrm{Cd}}$ & - & $16.30 \pm 0.04^{\mathrm{Bc}}$ & $27.12 \pm 0.17^{\mathrm{Ab}}$ \\
\hline
\end{tabular}

${ }^{a} \mathrm{HWD}$ : Hot water dipping; MAP: Modified atmosphere packaging; $\mathrm{CO}_{2}$ : Carbon dioxide gas; $\mathrm{N}_{2}$ : Nitrogen gas. Figures in parentheses indicate the standard deviation. Values with the same lowercase superscript in each column or uppercase superscript in each row are not significantly different $(\mathrm{p}>0.05)$.
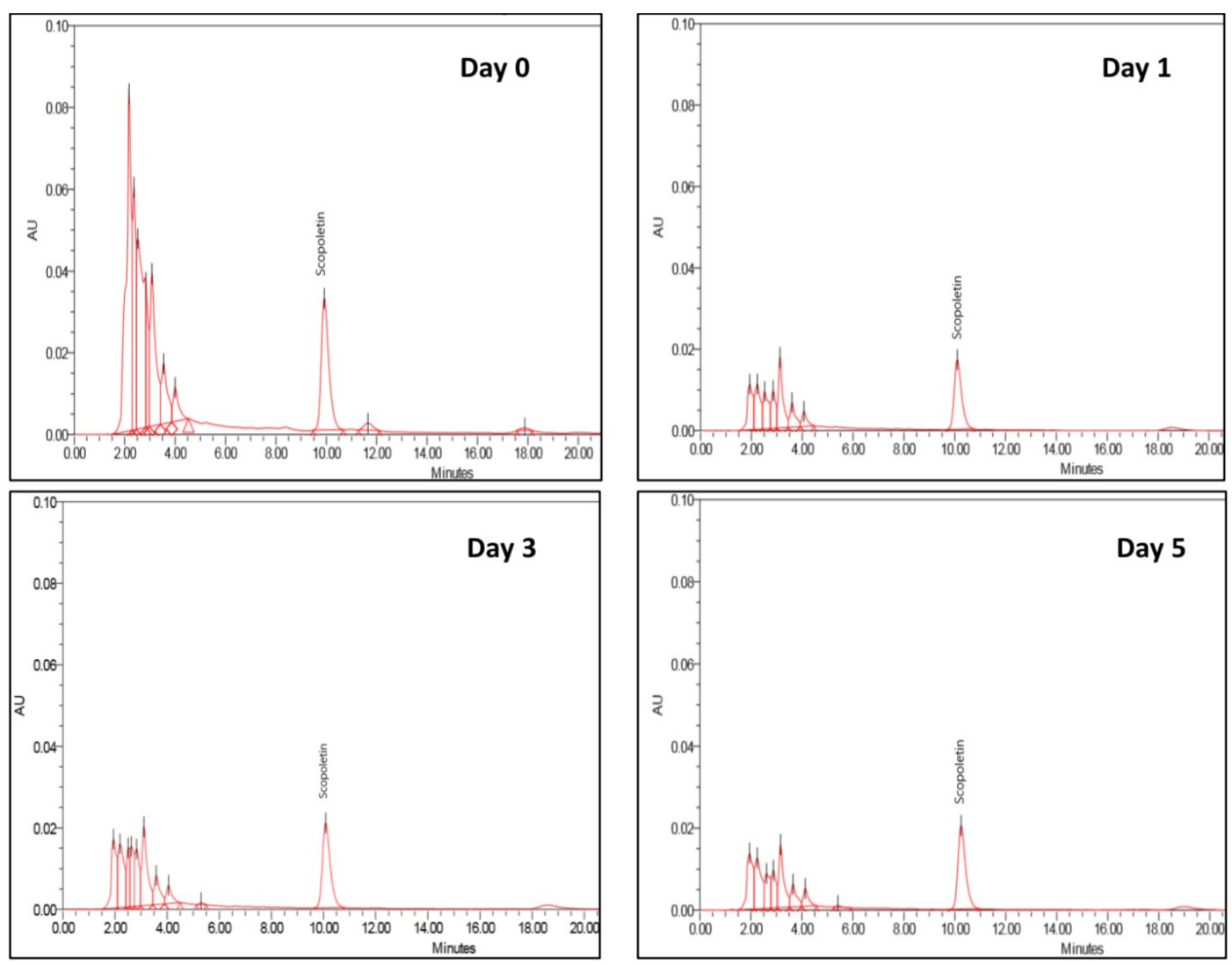

Figure 3. Typical HPLC chromatograms of scopoletin content in Noni during storage

concentration on day 0 and began to decrease and stagnant from day 3 to 5 , in agreement with a study by Chan-Blanco et al. (2007). They reported that the scopoletin content increased as the fruit ripened, remaining constant during ageing. The maturity of noni varied with different nutritional values. Setyaningsih and Subekti (2019) claimed that noni fruit has the highest scopoletin content when the fruit is nearly ripe.

Interestingly, for both $\mathrm{CO}_{2}$-based and $\mathrm{N}_{2}$-based MAP treatments, scopoletin concentration decreased and increased significantly $(\mathrm{p}<0.05)$ after day 3 of storage. Both MAP treatments had a higher scopoletin content, as shown in Table 3, proving that the MAP method efficiently accumulated scopoletin compared to the control and HWD treatments. According to Dziedzic et al. (2020), MAP treated blue honeysuckle fruits had more bioactive compounds compared to those stored at room temperature. In addition, Khorshidi et al. (2011) reported that MAP increased the gas concentration in the system, leading to abiotic stress, causing the accumulation of secondary metabolites, including bioactive compounds in fruits. Similarly, Buschmann et al. (2000) reported that scopoletin in cassava roots was high directly after harvesting due to its response to harm. There was a decline in scopoletin content, followed by an increase after six days due to the defensive response towards microbial growth. Also, scopoletin acts as an anti-microbial agent at the infected part, with a ten-fold increase in the scopoletin content (Peterson et al., 2003). However, moderate negative correlations were recorded between the scopoletin content and $a^{*}(\mathrm{R}=-0.481$, $\mathrm{p}<0.05)$ and $b^{*}(\mathrm{R}=-0.499, \mathrm{p}<0.05)$, suggesting that the decrease in scopoletin content also reduced the greenness and yellowness of noni flesh.

\section{Conclusion}

This study reported the effect of different postharvest treatments on the physicochemical stability of noni. 
According to the results, even though control treatment fruit had a longer shelf life than other treatments, the quality and stability of noni were not maintained. Heat treatment is a common technique used in industry; however, the HWD treatment used in this study affected the quality and shortened noni's shelf life. Interestingly, MAP treatments were found to efficiently preserve the Noni, with a lower weight loss, TSS, TA and TCD and higher firmness and scopoletin content observed during storage. Comparing the two MAP treatments, resulted in significantly $(\mathrm{p}<0.05)$ firmer fruit with a higher scopoletin content than the $\mathrm{CO}_{2}$-based MAP, indicating that the $\mathrm{N}_{2}$-based MAP postharvest treatment is best to efficiently maintain the stability and quality of noni during storage.

\section{Conflict of interest}

The authors declare no conflict of interest.

\section{Acknowledgements}

The authors are grateful to the Ministry of Education Malaysia for a research grant (FRGS/1/2020/STG04/ UPM/02/6) awarded to Ezzat, M.A.

\section{References}

Amin, M.N. and Hossain, M.M. (2013). Reduction of Postharvest Loss and Prolong the Shelf-Life of Banana through Hot Water Treatment. Journal of Chemical Engineering, 27(1), 42-47. https:// doi.org/10.3329/jce.v27i1.15857

Arendse, E., Fawole, O.A. and Opara, U.L. (2014). Influence of storage temperature and duration on postharvest physico-chemical and mechanical properties of pomegranate fruit and arils. CyTAJournal of Food, 12(4), 389-398. https:// doi.org/10.1080/19476337.2014.900114

Askar, A. and Treptow, H. (2013). Quality assurance in tropical fruit processing. Berlin Heidelberg, Germany: Springer Science and Business Media.

Azman, E.M., Charalampopoulos, D. and Chatzifragkou, A. (2020). Acetic acid buffer as extraction medium for free and bound phenolics from dried blackcurrant (Ribes nigrum L.) skins. Journal of Food Science, 85 (11), 3745-3755. https://doi.org/10.1111/17503841.15466

Basar, S., Uhlenhut, K., Högger, P., Schöne, F. and Westendorf, J. (2010). Analgesic and antiinflammatory activity of Morinda citrifolia L. (Noni) fruit. Phytotherapy Research: An International Journal Devoted to Pharmacological and Toxicological Evaluation of Natural Product Derivatives, 24(1), 38-42. https://doi.org/10.1002/ ptr.2863

Buschmann, H., Rodriguez, M.X., Tohme, J. and Beeching, J.R. (2000). Accumulation of hydroxycoumarins during post-harvest deterioration of tuberous roots of cassava (Manihot esculenta Crantz). Annals of Botany, 86(6), 1153-1160. https:// doi.org/10.1006/anbo.2000.1285

Chan-Blanco, Y., Vaillant, F., Pérez, A.M., Belleville, M.P., Zúñiga, C. and Brat, P. (2007). The ripening and aging of Noni fruits (Morinda citrifolia L.): microbiological flora and antioxidant compounds. Journal of the Science of Food and Agriculture, 87 (9), 1710-1716. https://doi.org/10.1002/jsfa.2894

Chang, W.C., Wu, S.C., Xu, K.D., Liao, B.C., Wu, J.F. and Cheng, A.S. (2015). Scopoletin protects against methylglyoxal-induced hyperglycemia and insulin resistance mediated by suppression of advanced glycation endproducts (AGEs) generation and antiglycation. Molecules, 20(2), 2786-2801. https:// doi.org/10.3390/molecules20022786

Chunhieng, T., Hay, L. and Montet, D. (2005). Detailed study of the juice composition of Noni (Morinda citrifolia) fruits from Cambodia. Fruits, 60(1), 1324. https://doi.org/10.1051/fruits:2005008

Deng, S., Palu, A.K., West, B.J., Su, C.X., Zhou, B.N. and Jensen, J.C. (2007). Lipoxygenase inhibitory constituents of the fruits of Noni (Morinda citrifolia) collected in Tahiti. Journal of Natural Products, 70 (5), 859-862. https://doi.org/10.1021/np0605539

Dziedzic, E., Błaszczyk, J., Bieniasz, M., Dziadek, K. and Kopeć, A. (2020). Effect of modified (MAP) and controlled atmosphere (CA) storage on the quality and bioactive compounds of blue honeysuckle fruits (Lonicera caerulea L.). Scientia Horticulturae, 265, 109226.

https://doi.org/10.1016/ j.scienta.2020.109226

Giongo, L., Poncetta, P., Loretti, P. and Costa, F. (2013). Texture profiling of blueberries (Vaccinium spp.) during fruit development, ripening and storage. Postharvest Biology and Technology, 76, 34-39. https://doi.org/10.1016/j.postharvbio.2012.09.004

Golden, K.D. and Lindsay, C. (2012). Morinda citrifolia: amino acid and lipid content of the Noni fruit at various stages of maturity. Journal of Scientific Research, 4(2), 467-467. https://doi.org/10.3329/ jsr.v4i2.8130

Grigio, M.L., Durigan, M.F.B., Chagas, E.A., Chagas, P.C., Nascimento, C.R.D. and Almeida, M.S. (2015). Post-harvest conservation of camu-camu fruits (Myrciaria dubia (Kunth) Mc Vaugh) using different temperatures and packages. Food Science and Technology, 35(4), 652-658. https:// 
doi.org/10.1590/1678-457X.6788

Hazbavi, I., Khoshtaghaza, M.H., Mostaan, A. and Banakar, A. (2015). Effect of postharvest hot-water and heat treatment on quality of date palm (cv. Stamaran). Journal of the Saudi Society of Agricultural Sciences, 14(2), 153-159. https:// doi.org/10.1016/j.jssas.2013.10.003

Hossain, M., Rana, M., Kimura, Y. and Roslan, H.A. (2014). Changes in biochemical characteristics and activities of ripening associated enzymes in mango fruit during the storage at different temperatures. BioMed Research International, 2014, 232969. https://doi.org/10.1155/2014/232969

Janick, J. and Paull, R.E (Eds). (2008). The Encyclopedia of Fruit and Nuts. Wallingford, United Kingdom: CAB International. https:// doi.org/10.1079/9780851996387.0000

Kader, A.A. (2002). Postharvest technology of horticultural crops. $3^{\text {rd }}$ ed. University of California, USA: Agriculture and Natural Resources.

Kerbel, E.L., Mitchell, F.G. and Mayer, G. (1987). Effect of postharvest heat treatments for insect control on the quality and market life of avocados. HortScience, 22(1), 92-94.

Khorshidi, S., Davarynejad, G., Tehranifar, A. and Fallahi, E. (2011). Effect of modified atmosphere packaging on chemical composition, antioxidant activity, anthocyanin, and total phenolic content of cherry fruits. Horticulture, Environment, and Biotechnology, 52, 471. https://doi.org/10.1007/ s13580-011-0027-6

Koseki, S. and Itoh, K. (2002). Effect of nitrogen gas packaging on the quality and microbial growth of fresh-cut vegetables under low temperatures. Journal of Food Protection, 65(2), 326-332. https:// doi.org/10.4315/0362-028X-65.2.326

Kristjánsson, M.M. and Ásgeirsson, B. (2002). Properties of Extremophilic Enzymes and Their Importance in Food Science and Technology. In Handbook of Food Enzymology. New York, USA: Marcel Dekker.

Li, C.L., Han, X.C., Zhang, H., Wu, J.S. and Li, B. (2015). Effect of scopoletin on apoptosis and cell cycle arrest in human prostate cancer cells In vitro. Tropical Journal of Pharmaceutical Research, 14(4), 611-617. http://dx.doi.org/10.4314/tjpr.v14i4.8

Linke, M. and Geyer, M. (2013). Condensation dynamics in plastic film packaging of fruit and vegetables. Journal of Food Engineering, 116(1), 144-154. https://doi.org/10.1016/j.jfoodeng.2012.11.026

Liu, Q., Janssen, M.H., van Rantwijk, F. and Sheldon, R.A. (2005). Room-temperature ionic liquids that dissolve carbohydrates in high concentrations. Green Chemistry, 7(1), 39-42. https://doi.org/10.1039/ B412848F

Lopez-Castaneda, J., Corrales-Garcia, J., TerrazasSalgado, T. and Colinas-Leon, T. (2010). Effect of saturated air heat treatments on weight loss reduction and epicuticular changes in six varieties of cactus pear fruit (Opuntia spp.). Journal of the Professional Association for Cactus Development, 12, 37-47.

Macpherson, H., Daniells, J., Wedding, B. and Davis, C. (2007). The potential for a new value adding industry for Noni tropical fruit producers. Australia: Rural Industries Research and Development Corporation.

Moon, P D., Lee, B.H., Jeong, H.J., An, H.J., Park, S.J., Kim, H.R., HoKo, S.G., Um, J.Y., Hong, S.H. and Kim, H.M. (2007). Use of scopoletin to inhibit the production of inflammatory cytokines through inhibition of the I $\mathrm{KB} / \mathrm{NF}-\kappa \mathrm{B}$ signal cascade in the human mast cell line HMC-1. European Journal of Pharmacology, 555(2-3), 218-225. https:// doi.org/10.1016/j.ejphar.2006.10.021

Nelson, S.C. (2003). Proceedings of the 2002 Hawai'i Noni Conference. In 2002 Hawai'i Noni Conference. Hawaii, USA: Cooperative Extension Service, College of Tropical Agriculture and Human Resources, University of Hawai'i at Mānoa.

Park, Y. and Jung, S. (1996). Effects of storage temperature and preheating on the shelf life of yuzu during storage. Journal of the Korean Society for Horticultural Science, 37(2), 285-291.

Paull, R.E. and Chen, N.J. (2000). Heat treatment and fruit ripening. Postharvest Biology and Technology, 21(1), 21-37. https://doi.org/10.1016/S0925-5214 (00)00162-9

Peterson, J.K., Harrison, H.F., Jackson, D.M. and Snook, M.E. (2003). Biological activities and contents of scopolin and scopoletin in sweet potato clones. HortScience, 38(6), 1129-1133. https:// doi.org/10.21273/HORTSCI.38.6.1129

Perez, K., Mercado, J. and Soto-Valdez, H. (2004). Note. Effect of storage temperature on the shelf life of Hass avocado (Persea americana). Food Science and Technology International, 10(2), 73-77. https:// doi.org/10.1177\%2F1082013204043763

Ranganna, B.G.S.V., Raghavan, G.S.V. and Kushalappa, A.C. (1998). Hot water dipping to enhance storability of potatoes. Postharvest Biology and Technology, 13(3), 215-223. https://doi.org/10.1016/ S0925-5214(98)00015-5

Rethinam, P. and Sivaraman, K. (2007). Noni (Morinda citrifolia L), the miracle fruit-A holistic review. 
International Journal of Noni Research, 2, 4-34.

Rosalizan, M.S., Rohani, M.Y. and Khatijah, I. (2010). Physico-chemical characteristics of Morinda citrifolia fruit during growth and maturation. Journal of Tropical Agricultural and Food Science, 38(1), 21 -30 .

Serdar, H. and Usanmaz, S. (2017). Effects of Size, Storage Duration, and Modified Atmosphere Packaging on Some Pomological Characteristics of Wonderful Pomegranate Cultivar. In Kahramanoglu, I. (Ed.) Postharvest Handling. InTech Open E-Book. https://doi.org/10.5772/67914

Setyaningsih, E. and Subekti, S. (2019). The effect of Noni fruits (Morinda citrifolia) with different ripeness stages against the total erythrocytes and leukocytes of comet goldfish (Carrasius auratus) infested by Argulus. IOP Conference Series: Earth and Environment Science, 236, 012083. https:// doi.org/10.1088/1755-1315/236/1/012083

Shen, Y., Zhong, L., Sun, Y., Chen, J., Liu, D. and Ye, X. (2013). Influence of hot water dip on fruit quality, phenolic compounds and antioxidant capacity of Satsuma mandarin during storage. Food Science and Technology International, 19(6), 511-521. https:// doi.org/10.1177\%2F1082013212457669

Singh, B. and Sharma, R.A. (2020). Indian Morinda species: A review. Phytotherapy Research, 34(5), 924-1007. https://doi.org/10.1002/ptr.6579

Singh, D.R., Srivastava, R.C., Chand, S. and Kumar, A. (2007). Morinda citrifolia L.-An evergreen plant for diversification in commercial horticulture. International Journal of Noni Research, 2(1-2), 4258.

Sui, Y., Wisniewski, M., Droby, S., Norelli, J. and Liu, J. (2016). Recent advances and current status of the use of heat treatments in postharvest disease management systems: Is it time to turn up the heat? Trends in Food Science and Technology, 51, 34-40. https://doi.org/10.1016/j.tifs.2016.03.004

Thirukkumar, S., Vennila, P., Kanchana, S. and Uma Maheswari, T. (2017). Studies on Extraction of Juice from Noni Fruits (Morinda citrifolia Linn.). Indian Journal of Natural Sciences, 7(40), 11988-11994.

Vieille, C. and Zeikus, G.J. (2001). Hyperthermophilic enzymes: sources, uses, and molecular mechanisms for thermostability. Microbiology and Molecular Biology Reviews, 65(1), 1-43. https:// doi.org/10.1128/mmbr.65.1.1-43.2001

Vipul, U., Neeru, S., Amit, T.K., Joshi, H.M., Amreesh, M., Brijpal, S. and Bahadur, K.S. (2013). Standardization of HPLC method of scopoletin in different extracts of Convolvulus pluricaulis.
International Journal of Pharmaceutical Sciences and Drug Research, 5(1), 28-31.

Wang, M.Y. and Su, C. (2001). Cancer preventive effect of Morinda citrifolia (Noni). Annals of the New York Academy of Sciences, 952(1), 161-168. https:// doi.org/10.1111/j.1749-6632.2001.tb02737.x

Wrolstad, R.E. and Smith, D.E. (2017). Color Analysis. In Nielsen S. (Ed.) Food Analysis. Food Science Text Series. Cham, Switzerland: Springer. https:// doi.org/10.1007/978-3-319-45776-5_31

$\mathrm{Wu}, \mathrm{T}$., Li, M. and Lan, Z. (2019). Reveal the variation Patterns of Chemical Composition in the Fruit of Morinda citrifolia (Noni) during Postharvest Storage through Metabolomic Characterization. Tropical Plant Biology, 12(2), 85-97. https://doi.org/10.1007/ s12042-019-09222-6

Yahia, E.M. (Ed.). (2011). Postharvest biology and technology of tropical and subtropical fruits. Volume 1: Fundamental issues. Cambridge, UK: Woodhead Publishing Limited.

Yuan, L., Bi, Y., Ge, Y., Wang, Y., Liu, Y. and Li, G. (2013). Postharvest hot water dipping reduces decay by inducing disease resistance and maintaining firmness in muskmelon (Cucumis melo L.) fruit. Scientia Horticulturae, 161, 101-110. https:// doi.org/10.1016/j.scienta.2013.06.041

Zhou, Y., Deng, L. and Zeng, K. (2014). Crop Protection, 63, 89-96. https://doi.org/10.1016/ j.cropro.2014.05.015 